\title{
Idiomi v književnih delih slovenskega pisatelja Draga Jančarja
}

\author{
Jurij Rojs
}

V prispevku je predstavljena struktura idiomov v nekaterih izbranih delih pisatelja Draga Jančarja. Največ je takih s strukturo pridevnik + samostalnik, sledijo pa taki s strukturo glagol + samostalnik in glagol + predlog + samostalnik. Precej je avtorskih idiomov in citatov iz različnih jezikih, večinoma iz latinščine, manj pa je folklorizmov, elips, kletvic, fonetičnih besed ter medmetnih in transformacijskih stalnih besednih zvez.

Ključne besede: slovenščina, idiomatika, Drago Jančar

\section{Idioms in the literary works of the Slovenian writer Drago Jančar}

This article presents the structure of idioms in some selected works by the writer Drago Jančar. Most of them have the structure adjective + noun, followed by the structure verb + noun and verb + preposition + noun. Many of the author's idioms and quotations come from various languages, primarily Latin, and fewer are folklorisms, ellipses, swearwords, phonetic words, interjections, and transformations of phrasemes.

Key words: Slovenian, idiomatics, Drago Jančar

1 Med današnjimi različnimi pojmovanji vrst frazemov vsako vključuje ali samo jedro frazeološke sestave idioma ali frazema $\mathrm{z}$ analitičnim tipom pomena frazeološke zveze, ki s strukturo neposredno vplivajo na enote leksikalno-semantičnega sistema jezika, ali pa paremije (pregovore in reke), ki imajo istočasno dobesedni in preneseni pomen. Nekateri frazeologi vključujejo v frazeologijo samo dve vrsti frazemov: idiome in frazeološke zveze, drugi še pregovore in reke. K temu včasih dodajo še govorne šablone, raznovrstne klišeje in tudi krilatice. Vsi ti tipi enot so združeni glede na dve lastnosti: večbesednost (torej ločeno oblikovanje) in vzpostavljivost pomena.

Lahko bi tudi rekli, da spada v širok obseg frazeologije vse to, kar se vzpostavlja v že narejeni obliki, kar pa ni beseda. Takoj opazimo, da to merilo ni strukturno-semantično, ampak čisto uzualno: vse besedne zveze (BZ) (predikativne in nepredikativne) se vzpostavljajo v govoru ustrezno z uzusom uporabnosti, kar je predmet frazeologije.

Frazeologija je znanost o celotnem obsegu idiomatičnih BZ - to je leksikalna idiomatika. To lahko poimenujemo tudi frazematika, kolikor pač nastopajo idiomi 
- kot celota glede na nominativno strukturno-semantično organizacijo znakov in so lahko imenovani frazemi (Polivanov 1928; Telija 1996).

Idiomatika je jedro frazeologije, lahko celo rečemo frazeologija v ožjem pomenu, če le idiomi ustrezajo besedam glede na izpolnjenost teh ali drugih celostno nominativnih funkcij. $Z$ zadnjo razumemo sposobnost besednozvrstnosti, da izraženo z zvezo besed pokazati predmet, soodnosen $\mathrm{z}$ enim denotatom ( $\mathrm{z}$ razredom realij, dogodkov, pojavov, dejstev ipd.). Znaki se nanašajo na posamezno besedno vrsto, vstopajočo v zvezo besed.

Proces idiomotvornosti je pritegnitev besedne zveze v metaforo (ali drug trop) na osnovi podobnosti smisla, ki je izražen v osnovi nominativne »zamisli« in tistega, kar se označuje z zvezo besed in njenim »dobesednim « pomenom, temu pa je dodana še določena struktura védenja o svetu, nekakšen »scenarij《 ali »okvir« (kot se navadno govori v kognitivnih znanostih). Tako npr. staroruska BZ лезть на рожон spada $\mathrm{v}$ scenarij fragmenta lova na medveda: lovec je postavil kopje $\mathrm{s}$ pričvrščenim delom ostrine, medved se je nabodel, dal ostrino $\mathrm{v}$ žrelo, se razsrdil, s tem pa samega sebe pognal v smrt. Tu je prikazan »okvir«, tj. v obliki epizode strukturirana scena, večji fragment scenarija ali scenarij v celoti.

Idiomi se oblikujejo kot ekspresivno obarvani znaki. Nastopajo kot kentavri, $\mathrm{v}$ katerih je neki del prenesen, drugi pa nastopa v svojem neposrednem pomenu, kot npr. živeti na veliki nogi.

2 Leposlovna besedila Draga Jančarja smo izbrali naključno. Pričujoči izbor seveda še zdaleč ni dokončen, kaže le nekatere značilnosti pisateljeve frazeologije glede na strukturo.

\section{Pridevnik + samostalnik}

$» \ldots$ prebudilo me je tipkanje modernega adlerja « (SS, 172); »Rdeča armada se približuje Muri ... «(SPMS, 11, 14; SS, 66); »Kako se reče reševalni avto, nenadoma je znal samo še slovensko« (PP, 209); »Imena, gibi, stavki iz knjižice, s potiskanih in popisanih papirjev, pastelne barve, mirno dihanje znanih teles ... ( $(\mathrm{PP}, 140)$; "Zakaj nobena dobra beseda ga ni mogla odvrniti od njegovih misli« (SPMS, 61); »Pisarna z nekaj koščki pohištva, bodoči projektivni biro ...« (TI, 16, 39, 54); »Upokojenemu arhivarju Janezu Kostrinu se je v sredo življenje spremenilo iz enakomernega in mirnega toka v peklenski vrtinec duševnih bolečin « (SPMS, 87); »... potem se pač pojavite in mirna Bosna « (SS, 85); »Gradim vaški vodovod z udarno brigado« (TI, 15); »Avtobus je po vijugasti cesti rinil gor med ozke hribe« (PP, 279); »Pripraviti sem te hotel za višje cilje« (TI, 152, 155); »Prav gotovo je predaval o vzgoji volje. Ali o narodnem znanju mogoče. Da crkneš od dolgega časa« (TI, 139); »Saj to je prosti čas, brezdelje, zato so si izmislili nedelje « (SS, 12); »Res smo zadnje čase pogosto skupaj« (SS, 157); »Imela je gladko, nekoliko izbočeno čelo« (SPMS, 142); »Se pravi babje čenče in obrekovanja« (TOT, 32); »Prav gotovo se prvi hip ni mogel odločiti, ali ima pred seboj pijanega ali nevarnega ali nekoliko bebavega človeka « (SS, 5); »Bussolin je bil vitez, Bussolin je bil nenavadno dober človek ...« (SS, 127); »... z mastnimi črkami [je] natisnjeno ime čudnega kraja ...« 
(SPMS, 43); »Presenečenje je prišlo naslednji dan« (SS, 217); »Strah, da bi bil tukaj smešni profesor, ki v sončnem dnevu hodi naokrog z dežnikom ...« (PP, 192); »Ni ga prijavil in pri tem se je počutil kot očividec kaznivega dejanja « (SPMS, 82); »Usmilil se ga je nekdo za debele denarje« (VBV, 43); »Zdaj je v njem že risalna deska ...« (TI, 20); »Usul se je topel sipkast dež in že po nekaj minutah izginil« (PP, 135); »Odkod so se pravzaprav vzeli vsi ti narodi, ki jih še včeraj nikjer ni bilo, ali pa so varno počivali za železno zaveso, kvečjemu še kot devete dežele v kakšni literaturi? « (PIDD, 14); »Na mejah devete dežele naj ne bo nič« (PIDD, 17); »Duh, ki nas je doslej najbolj dušil, je bil zli duh malodušja« (TI, 200); »Živahna plesna glasba $\mathrm{z}$ oddaljenega plesišča ...« (TI, 125); »Popadla me je tiha groza ... mirna groza « (SS, 112); »Takšen hlapec, smrdeč po kmečkem gnoju ...« (SS, 197); »Kadar daje toplo hrano, pomeni, da je ena runda končana« (TI, 74); »... sem hodil za njegovim hrbtom, da ne bi zašel v njegov zorni kot« (SS, 71); »Zadeva se je umikala na rob črne kronike« (SS, 221 - idiom spada v okvir (sodobne) slovenske publicistike); »Zaslišal se je pasji lajež« (SPMS, 159, 163 - SSKJ: lajež psov - Jančar ima levi prilastek); »Fred ima na glavi cilinder, njegova žena gnezdo belih las in cvili« (PP, 78); »Bujni črni lasje so mu v lepih valovih padali na tilnik« (PP, 67, 193; SPMS, 30, 38); »Veter je dvigoval pšenične slovanske lase« (PP, 213); »Ti lasje so bili zdaj svetli in lahni« (PP, 111); »... da so se ji štrenasti lasje v velikih vzgibih premikali okrog glave« (PP, 123); »Vsa dolga leta bo poslušal šumenje, smeh in glasne pogovore ...« (SS, 155); »Ah, tisto tvojo kurbarijo bi se uredilo po partijski liniji« (TI, 80); »Groziš mu z ostro, zelo verjetno grožnjo; če je intelektualec, ga racionalno prepričaš, z železno logiko« (VBV, 87); »Svetloba je nastajala kakor sončna luč ...« (SS, 163); »Moral pa bi se na način logičnega sklepanja, z deduktivno metodo ... « (TI, 229 - knjižno); »... poglavitno je, da človek najde svoj notranji mir« (TI, 110); »Tolikokrat sem govoril, da človek s črnimi mislimi, ne sme v steno. Toda zdaj mislim, da uživaška sodrga pravzaprav nikoli nima črnih ali čudaških misli« (TI, 194); »Vedel sem, da je to popolnoma nora misel ...« (SS, 178); »Rani se pridruži tifusna mrzlica« (SPMS, 6). Pisatelj prepusti bralcu presojo starosti: »Bilo je stanovanje samskega moškega poznih srednjih let« (PP, 217); »Zakaj sem moral kričati v recepciji in tako na nek ovinkarski način prosjačiti za pomoč? « (SS, 113); »Svojega talenta ne bo izdajal v dobrodelne namene« (PP, 69 - tu gre za prohibitiv, ki je morfološko izražen z zanikanjem v zvezi z nedovršnim glagolom); »... jasno štajersko nebo« (SS, 121); »Nebo je lahko tudi modro« (SPMS, 140); »Bilo je tako toplo in dobro, kakor ta mehki in voljni sneg, kakor svetla mesečeva noč nad zemljo in nebo nad njo« (SPMS, 76); »Kostrin se je prestopil s svinčenimi nogami« (SPMS, 85). Somatizma sta tudi naslednja idioma v zloženi povedi: »Irenine pege, Lojzkine pege, vidne brez teleskopa na obeh straneh zavihanega nosu, slovanskega, sončne pege « (PP, 127); »Znano je, da imajo Židje orlovske nosove« (SS, 136). »Tako je bilo pozno popoldne, ko se je bližal večer in so kopasti oblaki pritiskali k tlom« (SPMS, 72); »Tale sanja z odprtimi očmi« (DAIN, 77); »... to je samo tisti zbegani pogled svetlih oči, skoraj sivih oči« (PP, 118); »Videl je njegove nevarne oči, ki so bile nekoliko steklene« (SS, 119); »Gumbo ga je gledal z vročičnimi očmi ...« (PP, 130); »Kadrovski si je mel roke in ga gledal z žarečimi očmi ...«(SPMS, 110); »Oprijel sem se za železno ograjo na dru- 
gi strani« (SS, 158); »Na drugi strani je videl moža v civilni obleki ...« (SPMS, 140). V eni povedi imamo kdaj več idiomov: »Poleg njega je sedel človek z bledim obrazom in odsotnim pogledom ... « (SPMS, 114). Jedrno besedo povezujeta dve komponenti: „Čisto pri miru sredi tega bradatega in spačenega obraza (SS, 6). »Naj slikajo njihove zdolgočasene obraze« (SPMS, 142); »Obup, črni obup. Za koga pišem, kje je še kak smisel, komu govorim? A to ti povem, ti ljudstvo, ti črna množica!«(DAIN, 48); »Pomislil je, kam bi spravil draga sončna očala, da se ne bi zdrobila!« (PP, 264). Vojaški stalni besedni zvezi (SBZ): »Na zemlji pa so žične ovire, minska polja ...« (PIDD, 16). »Prerinil se je v prve vrste in videl je, da so ga modre oči opazile« (SPMS, 93); »... taksist je imel v ogledalu rdeče oči od bedenja ...«(PP, 233); »Gospodična je imela vodeno modre oči« (PP, 23); »Kdaj pa je že on, Godot s svojimi plavimi očmi komu kaj storil« (TI, 244, 245, 245; PP, 163); »... zajec je imel rdeče oči, on pa plave, akvamarin« (TI, 245); »Oči so še svetlo modre, modre« (SPMS, 84); »[Volodja] gleda konico svojega čevlja, potem se z dirigentsko palico popraska po hrbtu ...«(VBV, 104); »Z okornega rečnega parnika so se oglasile piščali ...« (PP, 126); »Zaslišali so samotno ptičje petje« (TI, 158); »... bilo je slišati harmoniko in zatajeno petje « (SS, 178); »In v tem mestu se bodo kmalu paradni koraki zvrtinčili v nori, krvavi ples ...« (SS, 103 - ekspr. - idiom je produkt sekundarne nominacije); »Veliki gala ples« (VBV, 89); »Slikar Mrtvaškega plesa v Hrastovljah se stiska pod napušč cerkve, s katerega lije topli primorski dež na Istro ...« (PP, 140 - idiom je reminiscenca na slovensko slikarstvo); »V tem ... prosojnem sobotnem jutru plava smrt, tista s fresk na Mrtvaškem plesu ...« (PP, 275); »Njegov sorodnik z istim imenom je bil v tem mestu lastnik pogrebnega podjetja. Izgubil sem njegov naslov. Med pogrebnimi podjetji ga ni« (PP, 221); »Ko je vstala, ni dvignila pogleda« (PP, 163); »Ona je vendar govorila o družbenem položaju ...«(SPMS, 154); »... samo kukci grizljajo v svoji nočni uri svoj življenjski prostor pred seboj ... «(SPMS, 159); » ... so bile žrtvama šele tu prizadejane odločilne smrtne poškodbe« (SS, 210). Iz vojaškega izrazja je leksem in idiom: »... nemara nosi s seboj kakšno risbo tanka ali razstavljene avtomatske puške ...«(VBV, 49); »Simon piše na pisalni stroj « (VBV, 107; SPMS, 142, 149); »... medla svetloba ožarja zaspani voznikov obraz ...« (SPMS, 132); »Zdaj se je premaknil in stopil v zeleno modri pramen neonske svetlobe« (SPMS, 108; PP, 138, 138, 210); profesorski jedilnici je spet tiho žvenketal jedilni pribor« (PP, 97); »Kurenti, temne poganske prikazni ...« (SS, 174); »Ogrnjen je bil v tenko rožnato haljo, na kosmatih prsih mu je visela debela kovinska verižica« (PP, 234); »Dovolite, Mihael Vončina, sodelavec policijskega ravnatelja gospoda Krištofa Pajka« (DAIN, 33, 33). Slovenske družbene ureditve se dotika idiom: »Kakšna agrarna reforma, budalo« (TI, 220). »Tudi to noč, ko je stal pod Žigonovim oknom in mu je mrzli veter rezal sta$r e$ kosti, je mislil nanje «(SPMS; 105 - SSKJ: mraz reže do kosti); »Odsluži vojaški rok, ponovno se vpiše na trgovsko fakulteto ... « (SPMS, 41-42); »Obsojeni se mirno prepusti spremljevalcem, ki ga obkrožajo in z njim stopajo v soju ognjene svetlobe ... k pomladanskemu sončnemu siju « (SPMS, 63); »Tukaj piše v oklepaju, je dejal, v oklepaju piše: v osnovi odklanjanje vojaške službe« (SS, 147); »Tvoje sovraštvo do vsega postaja že bolestno, to je ... patološko sovraštvo« (SPMS, 155); 
»Zabavno je to, reče Ada, da se Anselmo bojuje proti veleposestnikom dobrega srca« (SPMS, 31); »Samo da konča pripravniški staž na sodišču« (PP, 98); »Bil je zgrbljen, redki lasje so mu moleli izza ovratnika kot šop slame iz poljskega strašila« (PP, 263); »Rezki in različni udarci pa so se razlili po mojem tkivu in mojem opojnem snu ...« (SS, 172); »Hkrati pa je bilo vse skupaj v moji sobi in vanjo je vdiralo rdeče žarenje uličnih svetilk. Ulične svetilke so rdeče ...«(SS, 172); »Njemu, kakor tudi drugim ljubiteljem znanosti, polarna svetloba ni pomenila ničesar tako zapletenega, česar ne bi bilo mogoče razložiti« (SS, 169); »Sholar mežika v sončno svetlobo« (SPMS, 60); »Če se vzpne po tem stožcu, pride tja do nebes, onkraj in še k drugim svetovom « (PP, 245); »Stekel je na ulico in dihal hladni svežec ...« (PP, 40); »Težak nočni šiht je bil to« (SPMS, 115);»... rada je govorila o svojih učnih urah in o predavanjih za izredne slušatelje te ali one politične šole ..." (SPMS, 142); »Njegova stara prijateljica je učiteljica marksizma na tehniški šoli« (SPMS, 121); »V naslednjih letih je Leopold Markoni mlajši končal trgovsko šolo« (SS, 152); »Vse to je premišljeval Gregor Gradnik, ko je zaman vrtel njeno telefonsko številko« (PP, 123, 241); »Ker te je imela partija rada, kot na začetku vse intelektualce in falirane študente ...« (TI, 46); »Izvedel pa sem za rasno teorijo« (SS, 128); »Neki moški z bikovskim tilnikom in gladko obritim obrazom je sedel poleg njega« (SS, 42); »Leden hlad čuti v prsih in gluho tišino ...« (SPMS, 14); »... zdaj je vanj udarila prazna tišina ulice ...« (SS, 5); »Balkan Sobranie. Dober tobak« (TI, 141); »... in flagranti, je stvar domnevanja, povezovanja in sklepanja, bistrega uma, intelektualna zadeva ...« (TI, 224); »Tisti prostor na koncu stranskega skladiščnega hodnika ga ne bo samo oropal vseh normalnih ambicij, ampak tudi zdravega uma« (SPMS, 155); »Kajti ljudje, ki so ga že slišali v nočni uri, ga ne imenujejo zaman smrtna ura« (SPMS, 158); »In rad sem jo imel na ležišču spalnega vagona ...« (SPMS, 141); »Ta položaj ti zagotavlja socialno varnost ...« (SPMS, 154); »Zunaj je bil hladen spomladanski večer« (SPMS, 88); »Gregor Gradnik je na obali reke, kjer vleče hladeči veter« (PP, 77). Veter je lahko hladen (TOT, 12), suh (PP, 212) in zahoden (PP, 212). »Mlado vino je oktobra« (VBV, 76); »Neka ženska se je na mile viže norčevala iz moje samotnosti« (SS, 178 - SSKJ: pog., ekspr.); »In potem se je škripaje ustavil smešni lokalni vlak« (PP, 239). Dva idioma sta v povedi: »Vsakemu komunistu mora biti jasno, da revolucionarno delo v tem trenutku ni več borba, niti državljanska vojna ...« (TI, 19). »Že tri tedne ni bilo tople vode (TI, 36); »Ali smo res pred izbruhom krvave svetovne vojne ...«(SS, 153); »Vidiš, je potem dobre volje nadaljeval« (SPMS, 103, 112). Antonim je »slabe volje« (SPMS, 115, 136). »Zdi se mi, da prav zdaj poslušajo glasbo. In niso najboljše volje« (PP, 236). Antonim pravkar navedenemu idiomu je v povedi: »Dajte no, tak humor. Naj gre tale ven,v slabo voljo me je spravil« (DAIN, 36). »Zelo trpim ob jutranjem ptičjem vrišču« (TI, 158); »Predavalnica ali seminar, ki je prostor ljubljanskega vseučilišča ...« (TI, 125); »Dunajske strehe, nad njimi je rdeč sončni $\operatorname{vzhod~«(TOT,~}$ 9). Nasprotje jedrni besedi je: »Pogled na vislice na Gavžniku. Prazne, a grozljive. Na ozadju rdečega sončnega zahoda« (TOT 130). »Takšnega poskusnega zajca, kot je bila Eva C., svet še ni imel« (SS, 33); »Tokrat so kopali prehode skozi snežne zamete« (PP, 222); »Kako si padel z neba, o Lucifer, jutranje zarje sin!« (PP, 15). 
Pisatelj Jančar slika tudi sprotna politična dogajanja, kot npr.: »Ah, Evropa, demokratična Evropa je boleča vprašanja $\mathrm{z}$ one strani železne zavese potisnila $\mathrm{v}$ gluho Faradayevo kletko tako imenovanega postkomunizma« (PIDD, 24). Somatizem črne zenice se nahaja dvakrat (SS, 6, 7). »Obrnjen je nov list v zgodovini dušeslovne znanosti« (VBV, 99); »Tisti kovinski zvok z letališča je votlo zvenel v ušesih ...« (PP, 242); »Svetloba se je valila po nebu kakor razbeljeni oblaki, vmes pa so prhutali svetlobni žarki kakor široki trakovi« (SS, 168). Živei so dobri, slabi in trdni (TI, 24), značaj pa je mlahav in trd (TI, 22, 24). Glagola delati in garati nastopata v zvezi z idiomom črna živina (TI, 96, 102); družbeno razslojenost izraža idiom v primeru »Medtem ko pripoveduje o fantu, ki je sin neke velike živine« (PP, 55).

\section{Glagol + samostalnik}

»Glih treba mu je bilo odkrivati Ameriko« (TI, 226); »In o vas gre glas, da ste blag človek« (DAIN, 27); »Toda tovariš Kostrin, je okrožni povišal glas« (SPMS, 104). Iz pogovornega jezika je vzet idiom v tejle zvezi: »On pa drži figo $v$ žepu« (VBV, 87). »Ko ste se vi borili, jaz pa sem si očitno praskal jajca v ujetništvu« (TI, 47 - vulg.); »Kadi cigareto za cigareto« (SPMS, 10). Pedagoško noto ima idiom: »Samo, tam je bil, jaz ti bom pa primazal Makarenkovo klofuto« (TI, 52). V naslednji povedi je v vsakem stavku po en idiom: »Tej objestnosti, ki čedalje bolj ogroža zdravega duha naše mladine, bi bilo treba napraviti konec « (TI, 171). »... V postrgano lice mu je udarilo še več krvi ... « (SS, 175, 176). Iz katoliške religije je naslednji idiom: »Vsak med nami mora nositi križ« (TOT, 155); »Temno je tukaj. Zakaj ne prižgeš luči? « (TI, 186); »V tem trenutku ugasne luč« (TI, 24); »Samo z njimi ravnajo ljudje surovo, sem si mislil, z menoj pa ne, mene pustijo pri miru ..." (SS, 115); »Prešinila me je prekleta misel ...« (SS, 178); »Pri šumenju morja ...« (TI, 134). Ekspresivna sta idioma: »Obnašaš se, kot da imam mačka ali kot da sem vstal z levo nogo« (VBV, 57); »Ali so se meni tako čudno bleščale oči ...? (SS, 116); »Tekst se je zaustavil, gladina se je umirila. Zaprl je oči. Odprl je oči« (PP, 7); »... tja do jutra ni mogel zatisniti očesa « (SS, 144 - SSKJ: ekspr.); »... jaz sem si pustil tam v tisti pisarni soliti pamet od nekakšnega policijskega uradnika (SS, 86); »Ko sem dvignil pogled ... « (SS, 159); »Očesci pa sta bili takšni, da ni mogoče odtrgati pogleda ...« (SS, 6); »Med tem Dedal Janku ponudi roko ...« (TI, 13 SSKJ: ekspr.); »Vasilka si prižge cigareto in stopi k Dedalu« (TI, 51; VBV, 50, 57); »Jelena prižge svečo pred ikono Matere božje in poklekne pred njo« (SPMS, 6); »Ni znal stisniti roke« (SS, 143-144). Sekundarna nominacija je tudi v idiomu: »Torej, zavihajmo rokave« (TI, 17); »nisem navajen, veste, je rekel, medtem ko je lovil sapo « (SPMS, 111); »Dvignil je sidro, ladja je plula, balon je vzletel« (PP, 229); »Vrlo dobro, bi morala zahrumeti množica ... in polkovnik bi moral odgovoriti ...: Služimo narodu. Vsa množica moških glasov je v en glas zakričala: Služimo narodu« (SPMS, 152); »Obrnil se je [polkovnik] k ljudstvu, se razkoračil, postavil roke v boke in vzkliknil: Vrlo dobro« (SPMS, 153). Korelativen je idiom: »Topli februarski veter je talil sneg « (SS, 175); »V New Yorku je snežilo, hodil je po umazani snežni plundri, tukaj, kjer na bi zmeraj sijalo sonce, tukaj je deževalo« (PP, 9). V obliki klimaksa nastopa idiom: »Živeti med ljudmi, ki so vam odprli svoj dom in svoja srca, da, tudi svoja srca ..." (SS, 126); »Bolniška soba v 
psihiatričnem zavodu - Svoboda osvobaja« (VBV, 39); »... in slišal je, kako mu v prsih bije srce« (SPMS, 113); »Glavina je stresal šale na njen in na moj račun, na najin račun « (SS, 206). Iz slenga je vzet idiom: »Sledi tisto, čemur se v vseh jezikih danes reče ,utrgan film" " (PP, 83). »Avtomat je z glavnim udarcem utrnil luč in pod nogami ji je zazevala tema« (SPMS, 144); »Potem Irma vključi gramofon, tiha ,njena' arija« (TI, 106); »Mir! Izklopi tisti prekleti gramofon« (TI, 106); »Mi nismo nikomur zaprli vrat, če je hotel vstopiti v našo hišo« (SS, 184); »Zatopil se je v branje (SPMS, 157 - SSKJ: ekspr.); »Ne verjamem, da so te more $v$ kakšni zvezi s čudnimi dogodki ...« (SS, 111). Notranji predmet je v idiomu: »... to se pravi živeti življenje enodnevnice« (TI, 137). »... nekoliko nepotrebnem sem izgubil živce« (SS, 113 - SSKJ: ekspr.); prav takšen je stilni kvalifikator v naslednjem idiomu:. »Ne žri mi živcev ... Samo ne nalivaj se, ne žri mi živcev« (TI, 46). - Zaporedje samostalnik + glagol izkazujejo idiomi: »Ni čudno, grdega mačka mora imeti« (VBV, 46); »Mislim, da se mi je glas nekoliko tresel« (SS, 133);»... s kamenjem in z meči odpustke delijo ...« (TOT, 26); »Kot da je to kakšna galerija, ne pa zavod Svoboda - osvobaja ...« (VBV, 94, 48, 49); »Vrag si ga vedi ... «(SS, 17); »Vrata so se vdala« (SS, 86, 112, 112);»... in spet so zvezde zasijale na nebu ...« (SS, 164).

\section{Glagol + predlog + samostalnik}

»Spet mi skačeta $v$ besedo ...«(TOT, 30); »Vse svoje je pustil na cedilu ...» (TOT, 50; SS, 110); »Lepše je pasti na višku moči in v cvetu življenja kakor dolgočasno segniti v smrtni postelji ...« (TI, 179); »Njemu je segla do duše« (TOT, 73 - SSKJ: ekspr. - tu je nadomeščena beseda srce); »Takole sem že popuščal nekaj časa, dokler mi nisi zrasel čez glavo« (TI, 246 - SSKJ: pog.); »V tisti temi sem gledal z odprtimi očmi v zid ...« (SS, 111); »Kajpada latinski psalter, ki ga nerazumljivo in brez andohti tulijo menihi, gre kvečjemu do trebuha« (TOT, 37); »... duhovno sodišče ga izobči $i z$ cerkve ...« (TOT, 50-51); »... stopimo še k Milki na kozarec« (TI, 188); »Nenadoma mi je prišlo na misel ...« (SS, 178 - SSKJ: ekspr.); »Ves dan je šel v nič« (PP, 38); »Njih lahko ima za norca. Jaz sem pa tu. Mene ne bo imel za norca« (DAIN, 79 - SSKJ: ekspr.); »... stopi tja v pisarno in se vrne s kosom papirja, ki mi ga pomoli pod nos ... «(SS, 136); »Vse si nas potegnil za nos « (SS, 190 - ta idiom izraža periferijo na področju obnašanja in je eden od tistih, ki označujejo prevaro tipa potegniti za nos, metati pesek $v$ oči, naliti čistega vina); "Ne razumeš me, ker te bom moral obsoditi na smrt« (TI, 89); »Nezadržno mi prihaja pred oči neka Boscheva slika« (SS, 73); »Tudi je vaša stvar, če ste si izbrali drugo družbo, je rekel in poblisnil z očmi proti Tondichterju ...« (SS, 126); »Vsakomur bi lahko pogledal v oči« (SPMS, 90); »Z mehkimi koleni je stopal med njima in temnilo se mu je pred očmi« (SPMS, 102); »... Žigon pa je samo odmahoval z roko« (SPMS, 118); »Kadrovski ga je jezno ošinil s svojim svetlo modrim pogledom « (SPMS, 93); »Tondichter se je odmaknil in ga premeril z užaljenim pogledom « (SS, 126); »Samo malo še manjka in vse bo prišlo na dan« (SPMS, 95 - SSKJ: ekspr.); »Šele kadar Jezus zares omahne, takrat si Debil privošči kakšno na njegov račun« (PP, 200; DAIN, 16, 47, 32); »Skomignil sem $z$ rameni $\ll(S S, 125,130,217,200,221 ; P P, 213$; TI, 34, 187, 229, 260; VBV, 71); »Vsa vzhodnoevropska blebetanja o Evropi, o poti v Evropo, o čimprejšnji 
evropeizaciji je treba vzeti z rezervo« (PIDD, 13 - SSKJ: knjiž.). Precej je v pisateljevh delih frazeoloških somatizmov, kot npr.: »Vidite, šel sem vam na roko« (DAIN, 37 - SSKJ: pog.); »V kovček sem metal vse, kar mi je prišlo pod roke« (SS, 173); »Kaj, za hudiča, ne vidite, da je Wolfova usoda v vaših rokah « (DAIN, 39); "... in zdelo se mi je, da je zdaj zadnji hip, ko se še lahko vzamem v roke ..." (SS, 122; SPMS, 95 - SSKJ: ekspr.); »Videla sem te $v$ sanjah « (TI, 159); »Ko sem se zbudil iz sna ali tiste odsotnosti, sem skušal odpreti okno « (SS, 10); 》Gurte, človek bi počil od smeha «(SPMS, 90, 90); »Strigla je z ušesi, ampak naprej ni hotela « (SS, 189); »Že razumem, je rekel Kostrin občudujoče in se isti hip ugriznil v jezik« (SPMS, 115); »Lil Dagover, čudno lepa igralka, vrgla ga je iz tira« (SS, 12 - SSKJ: ekspr.); »Debil se je naslonila nazaj in bobnala s prsti. Liona je strigla $z$ ušesi« (PP, 160); »Žigon pa je samo zamahnil z roko« (SPMS, 118); »Enkrat mu zvoni $v$ ušesih, drugič se pojavi nenadno potenje ...« (PP, 243; SPMS, 154); »Bil je tukaj na začetku neke svoje zgodbe in vse mu je bilo na voljo (PP, 13); »... ob tej misli se mu je zameglilo pred očmi « (PP, 73 - SSKJ: ekspr.); »Dva dni je od jutra do večera taval po labirintih, mestu mrtvih, toda Joseph se je udrl $v$ zemljo «(PP, 70 - SSKJ: ekspr.); »Pri številki pet se je zrinil po stopnicah med sedečimi, objetimi fanti in dolgo pritiskal na zvonec« (PP, 234); »Zvenenje $v$ ušesih je prekinil čuden šum« (SPMS, 154); »Poslušaj ti, doktor. Tebi je tvoja znanost malo zlezla $v$ glavo« (VBV, 47).

\section{Prislov + glagol}

»Šla sva skozi snežno brozgo in čutil sem, kako me zdravnik postrani pogleduje izpod svoje kučme« (SS, 133); »Sploh ne veš, kako globoko si zabredel« (DAIN, 18 - SSKJ: ekspr.); »Zaprepadeno ga je pogledala ...«(SS, 122 - SSKJ: pog.).

\section{Predlog + zaimek + samostalnik}

$» \ldots$ meni se je zdelo, da smo na vsem svetu samo mi trije« (SS, 185); »Proti svoji volji sem odgovarjal surovo« (TI, 188-189).

\section{Samostalnik + glagol + pridevnik}

»... nos ima otroško sploščen ...«(PP, 141); »Bila je objokana, njene oči so bile spet žalostne ...« (PP, 124); »Je to takšen greh? - Do neba vpijoč $($ TOT, 168).

\section{Predlog + samostalnik + samostalnik}

»Ti se ne zavzemaš zanj - plahun si in v očeh javnosti diskreditiran«(DAIN, 32-33); »Vse, kar je živega in kar prihaja, potisniti na dno srca, zazidati« (PP, 236-237).

\section{Predlog + samostalnik + glagol}

»Na prste sem računal, koliko ur sem spal« (SS, 139); »Po prstih je stopil pred njegova vrata (SPMS, 91); »... z Jaroslavom [sva se] kje daleč na jugu in do vratu zakopana $\mathrm{v}$ posle ... « (SS, 12). Le enkrat smo zasledili strukturo:predlog + samostalniki + predlog + zaimek: »Kostrina ni zanimalo, ali je Žigon $v$ zvezi $s$ tistim, ki postavljajo ali mečejo bombe ..." (SPMS, 95). 
Predlog + samostalnik + predlog + samostalnik

»Kostrin je čutil, da je od glave do peta polit z gnojnico« (SPMS, 86); »Ko sem se zrinil v njegovo bližino, me je tako pogledal od pet do glave ..." (SS, 178 - SSKJ: ekspr.); »Nekdo je moral $z$ resnico na dan « (DAIN, 31); »Zadaj za oltarjem, ki sega od tal do stropa ...« (SS, 43);»... od vzhoda do zahoda korakajo mladi ljudje« (SS, 103).

\section{Predlog + števnik + samostalnik}

»... naj opravita te stvari med štirimi očmi« (SPMS, 85); »Zlasti pa hoče vedeti, kaj je notri v lobanji, in to hoče vedeti na prvi pogled « (SS, 123; VBV, 46); »To je treba rešiti z eno potezo« (TI, 182).

\section{Predlog + zaimek + samostalnik}

»Hotela sem zvedeti, za kaj gre. Saj vem, za kaj gre ...« (DAIN, 30; SPMS, 113); »Tovarišica, je zakričala na ves glas ...« (SPMS, 123, 247).

\section{Glagol + samostalnik + predlog + samostalnik}

»Ne morem reči, koliko časa je minilo, kako dolgo sem kadil cigareto za cigareto ...« (SS, 203); »Volodja potegne glavo med ramena« (VBV, 55 - SSKJ: od strahu potegniti, stisniti glavo med ramena); »Ne, pač pa je bilo dreka do kolen « (TI, 66); »... od vseh strani bo zavreščalo in zakričalo, da bo Gretici zledenela kri $v$ žilah« (SS, 156); »Kdaj pa je Volodja komu skrivil las na glavi?«(VBV, 59); »Toda ko je bilo to dvoje na mizi, je bilo vse tako enostavno in nazorno, da se mu je odvalil kamen od srca« (SPMS, 116 - SSKJ: ekspr.); "Ta se je naslonil na zid in prekrižal roke na prsih« (SPMS, 103); »... ob misli na neznosno obrekovanje, ki ga čaka, so mu stopile solze $v$ oči (SPMS, 90 - SSKJ: ekspr.); »Ana je takšna, kot bi izgubila tla pod nogami« (DAIN, 72); »V naši deželi se nosi glava v torbi« (TOT, 74, 74, 131, 167 - SSKJ: pog., ekspr.); »... in to je zmeraj polagal na srce mlademu Žigonu, človeku, ki mu je zdaj zasadil nož v srce« (SPMS, 89 - SSKJ: ekspr.). - Strukturo glagol + samostalnik + predlog + zaimek srečamo le tu in tam: »Vsi so se mu krohotali, on pa je izgubil sleherno oblast nad seboj« (SS, 177).

\section{Glagol + predlog + samostalnik}

»Spet mi skačete $v$ besedo« (TOT, 30); »Enajst let niti za hip ni posumil, kaj nakleplje in kaj ima za bregom« (SPMS, 12); »Jaz nikogar ne vlečem v nobeno godljo« (DAIN, 20 - SSKJ: ekspr.); »Na zborovanju profesorjev je škof udaril po mizi « (DAIN, 44); »Samo da je zdaj v kaši« (DAIN, 17); »Pristal bom na nekak usran kompromis« (DAIN, 33); »Ali ne tečejo tudi drugod potoki in kri ljudem po žilah?« (DAIN, 50); »Blato v organizmu razpada, prosim lepo, ali pride normalnemu človeku kaj takega na misel « (SPMS, 147-148 - SSKJ: ekspr.). Enak, le z nikalnico, je idiom v TI, 234. »Ni še daleč čas, ko smo si ob njihovih očitnih lažeh komaj upali drug drugemu pogledati v oči« (DAIN, 21); »En sam človek je od prvega trenutka vedel, da ne gre za požar, da se sile nebe$\check{s} k$ e pregibljejo in da bodo ljudje omrtveli od strahu ...« (SS, 163); »Kako je z 
njenim Franjom, ki ves zaripel v obraz ...« (SS, 48). - Le en primer nahajamo z glagolom in pridevniškim prislovom: »Irena sede po turško ...«(PP, 223). Tako tudi glagol + predlog + prislov: »Organizacija je prepričana, da ga je treba $\mathrm{v}$ trenutnih vse bolj zapletenih razmerah dati za nekaj časa na hladno (SPMS, 39). Enkrat najdemo tudi idiom pridevnik + samostalnik + prislov: »na smrt dolgočasno« (SS, 30).

Dvakrat srečamo idiom s strukturo glagol + predlog + samostalnik + predlog + samostalnik: »Kostrin je cepetal in se predeval z noge na nogo « (SPMS, 100). Sinonimno je jedro: »... in se prestopal z noge na nogo « (SS, 191). Dvakrat najdemo tudi strukturo glagol + zaimek + samostalnik: »... saj ni treba pregrizniti vsake besede« (SS, 203 - SSKJ: ekspr.). Takšno stilno vrednost ima tale SBZ: »Ni mogla verjeti svojim ušesom « (SPMS, 147). - Prislov + predlog + zaimek imamo v primeru »Pismo pravilno zaljubljene žene vse to vsebuje samo po sebi« (TI, 132). Redka je tudi struktura prislov + pridevnik: »Poznam pa še zelo dobro« (TI, 37); »prav dobro« (TI, 75).

\section{Prislov + veznik + prislov}

»Zajtrk sem obakrat izpustil. Hodil po glavni ulici gor in dol« (SS, 10, 13); ».. [ljudje] so hodili gor in sem in tja« (SS, 42); »Po ustih sem sem ter tja predeval tisto staro pecivo« (SS, 35, 37, 72); »... tu in tam sta spregovorila ... (SS, 152); »... zgoraj in spodaj ... " (SS, 111); »... slej ko prej ... « (SPMS, 35, 85 ); »... videvajo ga, kako hodi tja gor čez zasnežena polja « (SPMS, 11; PP, 249); »... pustil ga je čakati, prej ali slej bo spet njegov« (PP, 44); »Ona govori, ona s kozarcem v roki hodi pred kamionom sem in tja« (PP, 164); »Moškemu na ekranu, ki je še trenutek pred tem jezno hodil sem in tja ...« (PP, 165; SPMS, 58, 129;TOT, 14; PP 73, 109, 249; VBV, 39).

\section{Samostalnik + samostalnik}

"... na obletnici mature [so si] kazali fotografije svojih otrok ..." (SPMS, 133); »Ležali so na posteljah ali pa nemara sloneli ob oknih, zatopljenih vase in potopljeni v grgranje potočkov ... « (PP, 138); »... zdaj pa na vsakem vogalu najdeš napis: Drago, popravljalnica čevljev« $(\mathrm{PP}, 110)$; »Iz sosednjega prostora se v pramenu svetlobe, ki pada skozi odprta vrata, prikaže Ana« (DAIN, 50, 85; PP, 7, 281, 282); »Vstal je in videl sem, kako mu pramen sončne svetlobe rdeči lase na glavi« (SS, 82); »Kaj je torej čudnega, če ljudstvo tava $v$ temi, ko so omračeni celo tisti, ki bi morali biti luč sveta« (TOT, 13); »Vstopi Ignac. S knjigo pod pazduho in z velikanskim šopkom rož« (TI, 138, 151); »Stopil je do vrat in nazaj, se zasukal in se nekajkrat zavrtel v ritmu valčka ...« (SPMS, 151); »Sprva izrazitejša, potem se kakor s sunki vetra približuje in se v valovih spet umika ... « (125); »... ne vidim začetka in konca (SS, 56); »... skozi režo priprtih vrat pada žarek svetlobe ...« (PP, 58). Kdaj pa kdaj srečamo strukturo samostalnik + prislov: »... to ti rečem: Klobuk dol pred njim« (DAIN, 17). Z veznikom: »... bratstvo in enotnost « (PIDD, 11); »Moje solze so bile moj kruh dan in noč« (PP, 51; TOT, 118). 


\section{Samostalnik + predlog + samostalnik}

»Vse je bilo bob ob steno« (SPMS, 61 - SSKJ: ekspr.); »Na deželi hoče delati, in ko cerkovnik šaljivo pripomni: Bogu za hrbtom? mu trezno in rezko odgovori: Noben kraj ni Bogu za hrbtom « (SPMS, 7); »Kakšna je njegova kuharica? Kako naj se bojujem s takšno vojsko, skrokano, pijano, z vojsko, ki si dan na dan sladi in razvaja svoje čute ... « (DAIN, 45 - SSKJ: pog.); »Dan na dan in noč za nočjo ...« (DAIN, 45); »Raje vam bom prebral pesem o papežniku, ki dan na dan čez nas zmerja in mu je ime - Mrcina« (TOT, 119); »Kadar je vstopil kakšen gusar, kapucinar ali smrt $s$ koso, zavita v bele rjuhe ..." (SS, 276-277). Pomanjkanje fizičnih sposobnosti, pomanjkanje poguma, strah pred smrtjo ...«(SS, 138);»... bo pahnjen v najhujšo temo, kjer bo večno tuljenje in šklepetanje z zobmi« (TOT, 75); »Potem je metal kovance v igralni avtomat in brez misli potiskal na neke tipke« $(\mathrm{PP}, 208)$. Redke so tele strukture: samostalnik + predlog + prislov: »[Trgovina] je bila hkrati pisarna in poslovalnica za prodajo na debelo« (SS, 117); samostalnik + predlog + samostalnik + glagol: »Zemlja pod nogami se jim dviguje« (DAIN, 64); glagol + predlog + števnik + samostalnik: »Tu sva sama ... še je čas, da se pogovorite med štirimi očmi« (TOT, 152); predlog + pridevnik + samostalnik: »Prosim, da se v najkrajšem času sestanete s tovarišem projektantom ...« (TI, 17); »Premišljuješ lahko $v$ prostem času ...« (TI, 18). Le po enkrat imamo strukturo vrstilni zaimek + samostalnik: »... severni sij [je] odsev zlatih ščitov, na katerih nosijo boginje Valkire padle vojščake na drugi svet ... « (SS, 20, 171) in zaimek + pridevnik + samostalnik: »Ko sem bila majhna, takole, si ničesar na svetu nisem bolj želela, kot to, da bi smela ves ljubi dan tičati v tem prostoru« (DAIN, 41).

\section{Medmetni idiomi}

»Počasi, profesor. Najprej dober dan in dobrodošli« (DAIN, 36); »Dobro jutro« (VBV, 39); »Pa jebeš mu mater, kam gre ta svet? « (TI, 237 - vulg.); »Pa kdaj je tebi dobro, jebenti mater! « (TI, 95 - vulg.); »... brez takih, kot sem jaz, bi že zdavnaj vse skupaj šlo v božjo mater« (TI, 95); »Lahko noč. Noč. Dobro spi« (PP, 145)

\section{Zaimek + samostalnik}

»Sivolasi sodnik jo je hotel imeti ves čas ob sebi« (PP, 125); »Kakor da je bilo že ves dan v njegovem obnašanju nekaj, kar ga je s skrivnostno močjo tesnobno stiskalo« (SPMS, 44); »... za vse nakaznice, ki sta jih delili z obema rokama in jih poniževali ...« (TOT, 69); »Pljučnica spravi človeka na oni svet« (SPMS, 9; TI, 132; PP, 44); »Kdo pa bo dežural, vprašam, kdo na tem sfukanem svetu pa bo še sploh kdaj dežural? « (TI, 237); »Tistim postopačem in potepuhom razglasi, da izobča iz Svete matere cerkve njegovo veličanstvo« (DAIN, 65); »... ves dan in vso noč« (SS, 117).

\section{Zaimek + glagol}

»Ne vem, kaj me je pičilo ...« (SS, 107); »Ne vem, kaj se je skuhalo okrog mene« (SS, 112); »... a vam sem moral povedati, kar vam gre« (SS, 128); »Skoraj vsakemu se je posvetilo« (DAIN, 116). Osamljena je struktura zaimek + predlog + zaimek + glagol: 
»Kadar Fedjatin popije veliko žganja, začne sam s seboj govoriti po rusko ...«(SS, 157). Tako tudi: glagol + zaimek + predlog + zaimek: »... Franjo je ves iz sebe ...«(SS, 204).

\section{Idiomi s strukturo ne - ne}

$»$ V Ljubljani o vsem ni bilo ne duha ne sluha ...« (SS, 169); »... ni bilo ne konca ne kraja ...«(SPMS, 147).

\section{Sestavljeni vezniki kot idiomi}

»Všeč si mi kljub temu ...«(TI, 160; SS, 48); »Kljub čети ...« (TI, 160); »Kljub vsemu me ta Čeh pomirja« (SS, 15).

\section{Avtorski idiomi}

Te vrste idiomi niso slovarsko določljivi in so stvaritev avtorjeve besednozvezne vzpostavljivosti. Glede na primerjavo z drugimi vrstami idiomov so dokaj bogati. Gre za idiome, $v$ katerih je spremenjena komponenta (prenovitve), in tudi za take, ki jih ustvarja sam pisatelj Drago Jančar.

»Besede so visele v zraku« (PP, 97); »Moja stara mama pravi, da je za vsakega en cigel v arestu ( $\mathrm{TI}, 37$ ); »Kdor ima preveč duha, je tako ali tako na robu norosti, ta je pa že čez« (DAIN, 69); »Ga ne boš pustil, da grize svoj lastni rep?« (DAIN, 32); »Kostrin pa je zmeraj ležal na postelji, pokrit čez glavo in zvit v dve gubi« (SPMS, 87 - SSKJ: držati se v dve gubé 'sključeno'); »Človek, ki ga nihče nima rad, postane hudoben « (TI, 51); »Ta je prišel skozi ključavnico« (DAIN, 36); »Bolezen odhaja skozi ključavnico, prihaja pa skozi odprta vrata« (DAIN, 4 ); »... nenadoma mu je hladna mrščalica stekla po hrbtu in vsem telesu « (SPMS, 110); »Ko bo prišel čas, jim vržemo njihove štipendije pod noge« (DAIN, 44); »Njene oči so postajale ledeno mrzle« (SPMS, 122); »V kopalnici je gledal svoj zabuhli obraz z velikimi črnimi marogami pod očmi« (PP, 93); »... ima vso družbo in položaj v njej v malem prstu« (SS, 29 - pogosteje se rabi jedro mezinec); »... je rekel Okrožni in preluknjal Kostrina s svojim hladnim in ostrim očesnim rezilom « (SPMS, 97); »... tako ga je zdaj šumenje tablete, ki so se mu pridružili doslej popolnoma neznani zvoki, spravilo na rob nervoze« (SPMS, 138 - SSKJ: ekspr. biti, stati na robu obupa); »... spet je začel naletavati moker, cunjast sneg ...« (SS, 78); »... odpor do njegovega vinskega zadaha, se je mešal s strahom, ki mu je začel segati $v$ želodec « (SS, 119); »... oblivala ga je zeleno modra neonska svetloba z ulice ...« (SPMS, 114); »Če človek postane odvisen od strasti, je dana nevarnost, da zgrmi na tla njegov značaj« (TI, 145); »Ljubezen. To je edina veda, ki je predobro znana tudi tepcem « (TI, 129); »Toda najprej je treba zgraditi trdnjavo svobode, kot je dejal tovariš Marek« (TI, 23); »V lasten rep je ugriznil« (DAIN, 23); »Kaj se zdaj tu ven mažete«(VBV, 86); »Zagrizeš se $v$ knjigo, si kukec« (SPMS, 161); »Gospodje so različni, zastave se menjajo, meč se pa zmeraj enako suče ..." (TOT, 153); »Dober zidar zida dobro hišo« (TOT, 24); »In povem vam: to ta rogati, hudi zlodej dela « (TOT, 118); »No, tako sem ga pustil, da se precej časa paca v lastnem zosu «(SPMS, 116; TI, 228 - SSKJ: nizko); »Tisti njen krik, ki je šel skozi kosti in žilje telesa kakor rezilo« (SS, 161); »Do vhoda v votlino, ki je zijal kot črno žrelo ...« (SPMS, 52); »Ženska naj ljubi in je vesela« (TI, 140); »Ženska je na svetu zato, da ljubi, moški zato, da ustvarja« (TI, 134). 


\section{Pregovori in reki}

Ta razdelek je zastopan sorazmerno skromno, če upoštevamo veliko število slovenskih pregovorov in rekov. V obravnavanih delih pisatelja Draga Jančarja smo zasledili tele: »... konec dober, vse dobro, ni res? « (DAIN, 63); »Zakaj pa lažeš. Mene razburi, kadar pomislim, da ima laž kratke noge« (TI, 255-256); »Lep izgovor je dober, pa če ga mačka na repu prinese« (PP, 255 - Bojc 1980: Dober je izgovor, če ga tudi pes na repu prinese); »Siti lačnega ne razume« (TI, 213); »Nikoli ni prepozno« (TI, 64).

\section{Substituirani idiomi}

Tu gre največkrat za substitucijo komponente, večkrat je zamenjano jedro idioma. »Če izbereš bikovko, je pač bikovka, potem pač bikovka poje, ni res? « (SPMS, 116 - SSKJ: ekspr. kadar je nagajal, je pela šiba); »... tako naglo se je vse dogajalo to noč, da je bil že malodane brez uma ..." (SPMS, 126 - SSKJ: iz uma); »Miriade zvezd, miriade stvari na nebeškem svodu ..." (PP, 209 - SSKJ: nebesni svod); »Vergerij: Iz njegovih oči odsevata srditost in razdraženost, ki ju je opaziti le pri ljudeh, obsedenih od demona« (TOT, 118 - SSKJ: obseden od hudiča); »Zakon nature je tak, da iz majhnega rase veliko« (TI, 245 - SSKJ: iz malega); »Prižgal si je cigareto in puhnil modrikast dim pod oblake. Bili so črni, šele zdaj je videl, težki in kopasti« (PP, 230); »Previdnost je mast božja (TI, 208 - SSKJ: preg. previdnost je mati modrosti); »Požvižgam se na njihov dekret« (DAIN, 47 - SSKJ: ekspr. požvižgam se na ves svet); "Šel bi tja dol in ga ustrelil kot psa« (SPMS, 130 - SSKJ: ozmerjati koga kot psa; pobili so ga kot psa); »... prav gotovo imata prste vmes « (SS, 112); »Glavina je potegnil svojo glavo med ramena « (SS, 130); »Milka odloži svinčnik, gleda Klementa, zahihita se v pest « (TI, 133); »Upam, da mi kot nova upraviteljica Wolfove tiskarne ne boste odrekli strehe nad glavo« (DAIN, 29); »Ko je bilo pripravljenega govora konec, je zakopal glavo v dlani« (SS, 109, 109).

\section{Primerjalni idiomi}

Teh idiomov ni veliko, če jih primerjamo z avtorskimi. Našteli smo šest primerjav: »Gledal sem ga, ki je kakor blisk padel z neba« (PP, 15); »Bučalo je, kakor morje« (SS, 207); »... ponuja [se] nekaj razlag, nekaj razlag kot na dlani« (SS, 28 - SSKJ: pog.); »Na dolgem Broadwayu, ki se je vlekel kot jara kača, so utripale luči« (PP, 233); »Zeblo me je kot psa ...« (SS, 188); »Najlepše pa je bilo kolo. Stalo je tam na sliki kot plemenski žrebec« $(\mathrm{PP}, 61)$.

\section{Citati iz različnih jezikov}

Ta razdelek je dokaj bogat: »Et omnis lingua confitebitur Deo« (TOT, 123 - lat.: 'In vsak jezik bo slavil Boga'); »O miseras hominum mentes (TI, 170 - lat. 'O nesrečni duh človeški'); »... on ima ipso facto že dispozicijo« (TI, 130 - lat. 's samim dejanjem'); »Doktor: Freiheit macht frei!« (VBV, 102 - nem. 'Svoboda osvobaja'); »Jeseni štiriinštiridesetega bo stopil skozi železna vrata, na katerih bo pisalo Jedem das Seine« (SS, 166 - nem. 'Vsakomur svoje'); »Finis comoediae! Incipit tragoediae!« (TI, 81 - lat. 'Komedija je končana, začenja se tragedija'); »Ja, ampak 
- bil je lapsus linguae« (TI, 210 - lat. 'govorna pomota'); »Severni sij je nad našimi [.] kraji pomenil fata morgano ...« (SS, 170 - it. 'lažni privid'); »Pace suspecta tutius N bellum « (TI, 268 - it. 'Molči tako dolgo, dokler boj ni končan'); »Quam bene vivas - refert, non quam dio« (TOT, 151 - lat. 'Pomembno je, kako dobro živiš, ne, kako 저 dolgo').

\section{Citati v slovenščini}

»... enemu poštenemu, pravemu, dobremu pridigarju Juriju Juričiču njegovo ime jemljejo ... prava iver v očesu jim ni kobila, ampak poštena ženska, ki jo je Juričič vzel za svojo zakonsko ženo. Bruna v svojem očesu pa ne vidijo« (TOT, 119 - citat je vzet iz Evangelija po Mateju oz. po Luku: »Kaj vendar gledaš iver v očesu svojega brata, bruna v svojem očesu pa ne opaziš? « Mt 7,3 = Lk 6,41); »Človek - kako ponosno to je« (TI, 24 - M. Gorki); »Kdor z nožem maha, bo z nožem pokončan« (VBV, 75 - meč je zamenjan z nožem: Evangelij po Mateju 26,52); »Usoda ima rada ponavljanja, variacije, simetrije ... Ubijejo ga, toda on ne ve, da umira zato, da bi se ponovil nek prizor ...« (SPMS, 19 - J. L. Borges, Zaplet); »Kakšno religijo, opij za ljudstvo, mi zdaj tu zganjaš« (VBV, 99 - K. Marx - F. Engels); »Ali pa o mokrocvetečih rožcah poezije« (DAIN, 42, 71 - Prešeren, Sonetni venec, 4. sonet); »Vsem Slovencem gnado, mir, milost inu pravo spoznane skuzi Jezusa Kristusa prosim« (TOT, 95); »Naš narod mora živeti, tudi če moramo mi za to umreti« (SS, 150); »Ljubica (tiho poje): Beauty is so rare a thing /so few drink of my fountain / Lepota je tako redka stvar, / tako malo jih pije iz mojega vodnjaka« (VBV, 93). Jančar prenavlja tudi verz iz partizanske pesmi Bratje, le k soncu, svobodi: »Vzhod in Zahod se budita ...» (SS, 103 - v prepesnitvi Mileta Klopčiča: »Sever in jug se budita, drami se vzhod in zahod ...«).

\section{Preklinjevalni idiomi}

»Glasba je glasba, glasbo en drek brigajo režimi in ideologije« (SS, 102); »Teh ni veliko, npr.: »Glavina je rekel, da ga en drek briga, Nemci, Židje, Slovenci, vse ga en drek briga« (SS, 175 - SSKJ: vulg.); »Ne upaš si udariti, je rekel Glavina, en drek si upaš« (SS, 207); »Ignacij: Ne vidiš, da gre vse $k$ hudiču« (DAIN, 72, 41).

\section{Tavtološke frazeosheme}

»... samo Martinov pes, ki vse noči preleži med vrati lokala in od časa do časa dvigne težko oblomovsko glavo«: predl. od + sam. v rod. + predl. do + isti sam. v rod. (PP, 35; SPMS, 97, 126; SS, 163); »iz dneva $v$ dan«: predl. $i z+$ sam. v rod. + predl. $v+$ isti sam. v tož. (SPMS, 37, 90); »Njeni člani so morali ugotoviti, da kljub številnim predavanjem, neposrednemu delovanju med ljudstvom, od človeka do človeka, od duše do duše«: predl. od + sam. v rod. + predl. do + isti sam. v rod. (SS, 91-92); »... potujeta od kraja do kraja«: predl. od + sam. v rod. + predl. do + isti sam. v rod. (SS, 109); »Pravzaprav je moj pogled od obraza do obraza, od spake do spake, od lepotice do lepotice«: predl. od + sam. v rod. + 
predl. do + isti sam. v rod. (SS, 180); »Potovala sem torej od obraza do obraza«: predl. od + sam. v rod. + predl. do + isti sam. v rod. (SS, 183);»... od ust do ust gre govorica, da so Rusi v Avstriji«: predl. od + sam. v rod. + predl. do + isti sam. $\mathrm{v}$ rod. (SPMS, 11).

V Triptihu o Trubarju, v drugem poglavju z naslovom Nikdir dom, imamo reminiscenco na slovensko ljudsko pesem: »Neža začne nenadoma peti: ,Stoji mi, stoji poljece, / Oj polje široko.'«

\section{Fonetične besede}

Pri Jančarju so številne. Ne navajamo jih v povedi, marveč glede na strukturo, npr.: »en drek, en drek« (SS, 195 - vulg.); »ta hip« (PP, 140; TI, 143; SS, 85, 188; PIDD, 22); »v hipu « (SPMS, 129, 129, 149, 272; SS, 158; SPMS, 117); »za hip « (SS, 5, 6, 16, 195, 206, 209; SPMS, 92, 114, 165, 168; PP, 6, 9, 128, 244, 283; PIDD, 22); »za hipec« (SS, 188, 188); »čez čas« (SPMS, 92; SS, 100); »do dna« (SS, 193); »mar mi je« (DAIN, 62); »iz obupa« (SS, 201 - ekspr.); »in pika« (SPMS, 156; SS, 106); »pri priči« (SS, 201; PP, 35).

\section{Folklorni idiomi}

Ti so v obravnavanih delih zelo redki, npr.: »... nikjer ni bilo tako temno sredi belega dne ...« (SS, 17); »... pri belem dnevu« (SS, 79). Naslov dela »Poročilo iz devete dežele« je folklorno obarvan. Večkrat se ponovi idiom »deveta dežela« (PIDD, 7, 11 ...).

\section{Izpust ali elipsa}

»Saj ni treba do dna, se je omehčal« (SPMS, 113 - tj. izpiti, izprazniti); »Samotrpinčenje in orgije in goli čez drn in strn in vsega hudiča « (SS, 19 - tek); »Ne, je Ondra obupano odkimal ...« (SS, 19 - z glavo); »Mislil sem, da me bo kap tam pod havbo« (TI, 17 - izpuščeno zadela (SSKJ)); »Z mrzlo grozo razpoznava skrivnostno in nekoliko ironično pisavo usode, ki ga ni pripeljala sem, da bi ga odrešila in postavila piko« (SPMS, 14 - izpuščeno: na i); »S kolegi smo ga malo potegnili, kar od petka ...«(VBV, 39 - vinca, žganja, piva ipd.); »Temu človeku ni bilo mogoče do živega « (PP, 75 - tj. priti).

\section{Frazeološka transformacija}

$\mathrm{Tu}$ gre za substitucijo jedrne besede ali komponente, npr.: »Razburiš pa se hitro zadnje čase « (TI, 102); »Vsi trije bruhnejo v krohot « (VBV, 66). V romanu Posmehljivo poželenje imamo korelacijo na besedotvorni osnovi: »Včasih tako daleč, da človeku omrači um « (PP, 31 - SSKJ: omračitev uma). »Človeku ponudiš prst, on pa hoče še roko« (TI, 209 - SSKJ: Če mu prst ponudiš, pa roko z(a)grabi; Bojc 1980: Ko (mu) prst pomoliš, (za)grabi, prime za roko); »Volk kožo menja, dlake pa ne ...« (VBV, 75 - Bojc1980: Volk dlako (iz)premeni (menja), a nravi (čudi) nikdar). 


\section{- 3 Povzetek}

Tu je predstavljeno frazeološko gradivo iz nekaterih naključno izbranih del Draga Jančarja, pri čemer ni upoštevana kronološka razvrstitev in individualizacija junakov, ampak gre le za strukturo idiomov v osmih Jančarjevih knjigah iz njegovega obsežnega literarnega opusa.

\section{Kratice}

DAIN Blodniki: tri igre - Disident Arnož in njegovi

PIDD Poročilo iz devete dežele

PP Posmehljivo poželenje

SPMS Smrt pri Mariji Snežni

SS Severni sij

TI Tri igre

TOT Triptih o Trubarju

VBV Veliki briljantni valček

\section{Upoštevana dela Draga Jančarja}

Severni sij, Murska Sobota: Pomurska založba1984 (SS)

Smrt pri Mariji Snežni: novele, Ljubljana: MK, 1985 (SPMS).

Tri igre, Ljubljana: MK, 1988 (TI).

Blodniki: tri igre - Disident Arnož in njegovi, Maribor: Obzorja, 1982 (DAIN).

Triptih o Trubarju, Maribor: Obzorja, 1986 (TOT).

Posmehljivo poželenje, Celovec - Salzburg: Wieser, 1993 (PP).

Poročilo iz devete dežele, Celovec - Salzburg: Wieser, 1991 (PIDD).

Veliki briljantni valček, Ljubljana: DZS, 1977 (VBV).

\section{Literatura}

Baranov - Dobrovolski = A. Н. Баранов - Д. О. Добровольский, Аспекты теории фразеологии, Москва: Знак, 2008.

Bojc 1980 = E. Bojc, Pregovori in reki na Slovenskem, Ljubljana: DZS, ${ }^{2} 1980$.

Gantar 2007 = P. Gantar, Stalne besedne zveze v slovenščini: korpusni pristop, Ljubljana: ZRC SAZU, 2007 (Lingua Slovenica 3).

Keber 2003 = J. Keber, Frazeološki slovar slovenskega jezika: poskusni zvezek, Ljubljana: ZRC SAZU, 2003.

Kržišnik - Eismann 2007 = E. Kržišnik - W. Eismann (ur.), Frazeologija v jezikoslovju in drugih vedah $=$ Phraseologie in der Sprachwissenschaft und anderen Disziplinen $=$ Phraseology in linguistics and other branches of science $=$ Фразеология в языкознании и других науках, Ljubljana: Univerza v Ljubljani, Filozofska fakulteta, Oddelek za slovenistiko, 2007 (Europhras Slovenija 2005). 
Menac 2007 = A. Menac, Hrvatska frazeologija, Zagreb: Knjigra, 2007.

Polivanov 1928 = Е. Д. Поливанов, Введение в языкознание для языковедческих вузов, Ленинград, 1928.

SSKJ = Slovar slovenskega knjižnega jezika 1-5, Ljubljana: SAZU oz. ZRC SAZU (izd.) - DZS (zal.), 1970-1991.

Telija 1996 = В. Н. Телия, Русская фразеология, Москва, 1996.

Telija 2006 = В. Н. Телия, Большой фразеологический словарь русского языка, Москва: Аст-пресс книга, 2006.

Toporišič 1992 = J. Toporišič, Enciklopedija slovenskega jezika, Ljubljana: Cankarjeva založba, 1992 (Leksikoni, Sopotnik).

Žukov 1994 = А. Жуков, Русская фразеология, Москва, 1994.

\section{Идиомы в литературных произведениях словенского писателя Драго Янчара}

\section{Резюме}

В литературных произведениях современного словенского писателя Драго Янчара самыми многочисленными являются идиомы со структурой прилагательное + существительное. Вторыми по частоте использования являются структуры глагол + существительное, глагол + предлог + существительное Отмечается также значительное число авторских идиомов, а также цитат на разных языках (на латыни). В меньшем количестве встречаются фольклорные идиомы: клятвы и заклинания, междометия и звукоподражательные слова.

При этом важно отметить, что Драго Янчар - писатель, мастерски владеющих весьма разнородными стилями. Его герои говорят на правильном словенском языке - практически без диалектизмов. Случайные диалектизмы, если они появляются в тексте, понятны читателю без особых затруднений. При этом автор статьи придерживается мнения, что иностранных цитат в анализируемых произведениях слишком много, как переведенных, так и непереведенных. Определение структуры использованных идиомов осуществлено на основании случайной подборки произведений Драго Янчара, без попытки индивидуализации отдельных литературных героев. 